\title{
Analysis on Marketing Strategy of Small and Medium-sized Clothing Enterprises
}

\author{
Chunsheng Liu \\ Jiangxi Institute of Fashion Technology \\ Nanchang, Jiangxi, China 33020
}

\begin{abstract}
With current soaring development of economy and encouragement of national policies, many enterprises have stood in great numbers and market competition is also increasingly fierce. Small and medium-sized enterprises started from the founding of new China to the late 1970s and have flourished since the reform and opening up. As a national basic industry, clothing industry is labor intensive. Meanwhile, China can also provide plentiful raw materials of clothing. Domestic small and medium-sized clothing enterprises must use new marketing concept and strategy to assist the development of enterprise and maintain sound state under the circumstance that the clothing industries all over the world vie with each other. Taking small and medium-sized clothing enterprises as examples, this paper researches its marketing strategies and finds out problems, proposing valuable suggestions to improve its marketing strategies and competitiveness.
\end{abstract}

Keywords-small and medium-sized clothing enterprises; marketing strategy; strategy improvement

\section{INTRODUCTION}

At present, Chinese clothing accounts for $44.78 \%$ of export volume of clothing throughout the world. There are few local brands. They are exported in large number by OEM with low profit. However, clothing is the first among basic necessities of life, so clothing industry is still vital. People have increasingly high requirements for clothing. 99\% of clothing industry in national scale is small and medium-sized.

\section{CURRENT DEVElopMENT OF CHINESE SMALL AND MEDIUM-SIZED CLOTHING ENTERPRISES}

In recent years, international situation is complicated. Macro-economic situation in China is not optimistic. Small and medium-sized clothing market is sluggish with continuous sales volume declination and fierce competition. According to various data and investigations, small and medium-sized clothing enterprises are under great pressure of inventory. The performance quantity of clothing enterprises increases, resulting in upsurge of inventory. Total sales increase but book capital does exactly the opposite. The style of seasonal clothing updates fast. Stock products can only be disposed, which influences profit amount of enterprises. Inventory is one of the most important problems facing by clothing enterprises. Besides, although many clothing enterprises exist in China, there are few self-owned good brands, lacking unique design style. Many enterprises imitate the style to make profit.
Chinese clothing enterprises seldom spend energy in training designers and product design. Some excellent designers will leave the enterprise at length to create self-owned studios and brands. Moreover, some dealers lack consciousness of brand culture.

\section{SWOT ANALYSIS OF MARKETING STRATEGY OF SMALL AND MEDIUM-SIZED ENTERPRISES}

SWOT analysis has been used to analyze strategy and competition of enterprises since its appearance. It is an important analysis tool for modern business management. In small and medium-sized clothing enterprises in China, SWOT theory can analyze strengths and weaknesses as well as core competitiveness of them, and find out favorable factors inside and outside the enterprise, avoiding adverse factors in the development to guide benign development of enterprises finally.

\section{A. Analysis on Strengths}

Firstly, the pioneering advantage is low cost production. China abounds in raw materials, the price of which is more competitive than that of other countries. China has dense population with low price of labor force, superior in the two cost factors. However, in modern economy, merger and acquisition are easy to form between enterprises with similar industry type, which can expand scale of enterprises and strengthen profitability. At the same time, enterprises work closely with upstream enterprises in purchasing materials to realize high discount rate of material price. It shows plenty of small and medium-sized clothing enterprises boost profits through cost reduction in production.

Secondly, the quantity demanded in clothing is large. Most clothes in China are produced by small and medium-sized clothing enterprises. The financial crisis in 2008 made many small and medium-sized clothing enterprises go into liquidation. The demand for clothing in foreign countries declines rapidly, resulting in inventory accumulation and slow clothing production speed in China yearly after that. In recent years, Chinese economy has developed very fast, causing larger demand for clothing. The expenditure of Chinese consumers in clothing increases yearly. In 2015, the expenditure of urban residents in clothing increases $24.8 \%$, rural residents $20.3 \%$, reflecting huge consumption potentiality Therefore, the output of clothing increases ceaselessly. The output of clothing in 2015 is about 32.523 billion, $36.93 \%$ 
higher than 23.75 billion in 2008. Because of the excessive production in 2014 and 2015, the year-on-year data in 2016 show the overall production of clothing enterprises in the two years somewhat reduces. However, enterprises still regain confidence in the development because of strengths like big market, rapid economic growth and large cardinal number of people having demands in clothing.

Thirdly, it is influenced by national policies. Recently, China has introduced preferential policies to support the development of private enterprises. Measures like export rebates and subsidies are taken for traditional enterprises including small and medium-sized clothing enterprises. The government provides tax policy support, simplifies steps and increases efficiency, not only embodying the functions of the state, but also helping enterprises to get harmonious development and mutual benefit through cooperation.

\section{B. Analysis on Weaknesses}

Firstly, the target market is unclear. Small and mediumsized clothing enterprises often want to sell products instead of thinking about target customers. Many do not subdivide the existing market but go about several tasks at a time, failing to consider the accessibility, profitability and stability of markets. The selection of target market affects market positioning of enterprises. Now most enterprises publicize excellent quality and reasonable price of their products, neglecting features. Market segmentation is the premise and the selection of target market is the key in market strategy formulation.

Secondly, it lacks in self-owned brands. Chinese small and medium-sized clothing enterprises produce for others. The brand clothing around the world concentrates in Europe and America. National brands are absent in China at the present stage. The labor cost in China increases, so that many wellknown enterprises transfer to countries in Southeast Asia and many small enterprises are eliminated. In order to remain invincible, clothing enterprises in China must establish selfowned brands. However, because of weak brand maintenance and management and absence of self-independent innovation, medium-sized enterprises with self-owned brands imitate foreign clothing styles, resulting in slow brand development. As time passes, Chinese clothing enterprises have poor competitiveness because they cannot keep pace with fashion trend in the world.

Finally, products are short of innovation, having high degree of similarity. Chinese small and medium-sized clothing enterprises are weak in designing new products and imitate well-known brands. Because there are too many model enterprises, clothes designed by small and medium-sized clothing enterprises have high similarity without features. Besides, although some enterprises are capable of designing clothes with good style, they fail to invest too much in color and material quality like big enterprises. Great gap still exists between other enterprises and them.

\section{Analysis on Opportunities}

Firstly, the adjustment of tax policy has eased the burden of enterprises. The access of WTO and tariff preference has provided more convenient conditions for Chinese clothing enterprises in foreign trade. The tariff reduction lowers not only the import cost but also the foreign trade barrier of clothing enterprises. Document related to reform in valueadded tax was introduced in 2009, releasing the tax burden of small and medium-sized clothing enterprises. It proposes the adoption of value-added tax for consumption, deducting part of the taxes before taxes. After being issued formally, it can ease the tax burden of enterprises so that they can spend more capital in technology development and adjustment of industrial structure.

Secondly, it is the gap in middle and high-end market. Currently, consumers don't have functional requirements for clothing like keeping warm but pursue fashion to manifest taste. Therefore, to keep the leading position in small and medium-sized clothing industry, it is necessary to have topranking costume designer, advanced manufacturing technology and excellent marketing plan to manage enterprise personnel. At present, independent brands brought by new prominent designers are increasingly outstanding. Many designers have studios of their own. It is worthy of expecting for small and medium-sized clothing enterprises to capture middle and highend consumer market of independent brand in China if they are willing to cooperate with designers who have grasped fashion trend to create their own brands.

\section{Analysis on Threats}

Firstly, it is the threats from competitors. In the 1990s, the small and medium-sized clothing industry in China developed rapidly. Now there are more and more local clothing brands, including Peacebird, Goelia and Metersbonwe; second-line brands include Yishion, Semir and Tonlion, etc. Brands of Sino-foreign joint ventures include Etam, etc. Foreign wellknown fashion brands mainly include zara and Uniqlo, leading the world trends. At present, both domestic and foreign enterprises want to overwhelm competitors on brand, advertisement and price, fierce competition existing in small and medium-sized clothing market.

Secondly, it is the problem of marketing funds. Small and medium-sized clothing enterprises are not abundant in funds. It is difficult for them to raise funds because of the asymmetric information with lending institutions. Financial situation has direct relationship with capital allocation. Small and mediumsized enterprises with unscientific internal management cannot balance the relationship between production and sales very well, influencing marketing effect and finally the realization of market target.

To sum up, we have had in-depth understanding on strengths, weaknesses, opportunities and strengths of small and medium-sized clothing enterprises. In the market changing unceasingly, small and medium-sized clothing industries must research and develop independent products, seize the opportunity and expand the market, taking the development of middle and high-end market as strategic concept to further raise popularity of clothing brands and respond to increasingly fierce market competition at home and abroad. 


\section{SUGGESTIONS TO IMPROVE MARKETING STRATEGY OF SMALL AND MEDIUM-SIZED CLOTHING ENTERPRISES}

The first is "big marketing" strategy, the principal marketing mode in China, enabling small and medium-sized clothing enterprises to improve core competitiveness of clothing brands to better appeal to consumers. Products are the main factor of marketing. Improve features of products in accordance with in-depth understanding of consumers' requirements and local design elements to make most consumers satisfied with the products and recognize its value.

The second is the match between competitive strategies and competitive situation. At present, small and medium-sized clothing industry needs to face three competitive situations, including absolutely strong market, changing market and weak market. The changing market includes the market situation of enterprises formerly in strong market changes because of being uncompetitive, and the market competitiveness of enterprises formerly in weak market improves continuously on account of bold innovation.

\section{CONCLUSION}

According to development background, small and mediumsized clothing industry should make the best of its strengths accumulated in the market to help enterprises in weak market to beat competitors. In the same competitive market, on one hand, depend on competitive products to make up for the deficiency of uncompetitive products; on the other hand, overwhelm competitive products of competitors through the marketing strategy of "zero profit" for less competitive products. In the changing market, uncompetitive products can become pre-eminent through ceaseless improvement of brand influence of products and thinking on how to lead domestic fashion trends, giving more profit margins for dealers and defeating competitors on price.

\section{REFERENCES}

[1] Lu Changquan. Segmentation Marketing [M], China Machine Press, 2008.

[2] Alexander Ham, How to Do Well in Marketing [M], Enterprise Management Publishing House, 2000.

[3] Guo Guoqing, Qian Minghui. General Theory of Marketing [M], China Renmin University Press, Jan. 2007.

[4] [America] Eric Tyson, Jim Schell. How to Manage Small and Mediumsized Enterprises [M], Enterprise Management Publishing House, Jun. 2000.

[5] Fu Guoqun. Consumer Behavior [M], Higher Education Press, Jan.2010

[6] Lyu Yilin. Decision-making and Management of Marketing Channel [M], China Renmin University Press, 2005. 